\title{
Štete od bakrenastoga krasnika (Coleoptera, Buprestidae: Perotis lugubris fabricius 1777) i mogućnosti suzbijanja entomopatogenom gljivom
}

\section{Damages caused by the metallic wood-borinig beetle (Coleoptera, Buprestidae: Perotis lugubris fabricius 1777) and use of entomopathogenic fungi as potential biocontrol agent}

\author{
Tihomir Validžić ${ }^{*}$, Mladen Šimala ${ }^{2}$, Ankica Sarajlić ${ }^{3}$, Mirela Varga ${ }^{3}$, \\ Emilija Raspudićs ${ }^{3}$ Ivana Majić3 \\ ${ }^{1}$ Ministarstvo poljoprivrede, Uprava za stručnu podršku razvoju poljoprivrede i ribarstva, Ispostava Bizovac, 31000 Osijek \\ ${ }^{2}$ Hrvatska agencija za poljoprivredu i hranu, Centar za zaštitu bilja, 10000 Zagreb \\ ${ }^{3}$ Sveučilište u Osijeku, Fakultet agrobiotehničkih znanosti Osijek, 31000 Osijek \\ *Corresponding author E-mail address: tihomir.validzic@mps.hr (T. Validžić)
}

\section{Sažetak}

$\mathrm{U}$ radu su navedeni lokaliteti prvih nalaza bakrenastoga krasnika Perotis lugubris u nasadima šljive, višnje i lijeske na području istočne Slavonije i štete koje uzrokuje. Opisane su osnovne morfološke karakteristike. U laboratorijskom pokusu ispitana je učinkovitost biološkog insekticida na bazi entomopatogene gljive Beauveria bassiana protiv odraslih stadija bakrenastoga krasnika. Prema morfološkim značajkama utvrđeno je da bakrenasti krasnik pripada podvrsti P. lugubris lugubris, no potrebna su detaljnija morfometrijska istraživanja kako bi se potvrdio ovaj nalaz. Kritična brojnost bakrenastoga krasnika nije do sada istražena, no u našem istraživanju četiri imaga po sadnici načinila su $100 \%$-tnu štetu na pupovima mladih sadnica koštićavog voća. Bakrenasti krasnik osjetljiv je na entomopatogenu gljivu B. bassiana s obzirom na to da je nakon jednog tretmana kukaca biološkim sredstvom utvrđen mortalitet kod $60 \%$ jedinki. Od 5 do 7 dana nakon tretmana na uginulim jedinkama zamijećena je pojava micelija $B$. bassiana što je važno za potencijal horizontalne transmisije gljive na nove domaćine kukce.

Ključne riječi: Perotis lugubris lugubris, bakrenasti krasnik, kritična brojnost, biološki insekticid, Beauveria bassiana, učinkovitost

\begin{abstract}
The first occurence of the metallic wood-boring beetle Perotis lugubris in the area of Eastern Slavonia, and damages in plum, cherry and hazel plantations are reported by this study. Morphological characteristics and parameters of male genitalia and insect antennae were evaluated to identify the pest. The effectiveness of a commercial biological insecticide based on the entomopathogenic fungus Beauveria bassiana against the metallic wood-boring beetle adults was investigated under the laboratory condition. According to the insect morphological characteristics, the metallic wood-boring beetle was identified as subspecies $P$. lugubris lugubris, but detailed morphometric
\end{abstract}


studies are required to confirm this finding. The critical population abundance of the metallic wood-boring beetle has not been investigated so far, but in our study four pest adults per one seedling of stone fruit did $100 \%$ damage to the buds. The metallic wood-boring beetle is susceptible to $B$. bassiana, considering that after one treatment with a biological agent, mortality was achieved in $60 \%$ of insects. From 5 to 7 days after the treatment, the appearance of B. bassiana mycelium on cadavers was noticed which is important for the potential horizontal transmission of the fungus to a new insect hosts.

Keywords: Perotis lugubris lugubris, tresholds, biological insecticide, Beauveria bassiana, efficacy

\section{Uvod - Introduction}

Bakrenasti krasnik (Perotis (Aurigena) lugubris Fabricius 1777.) pripada redu tvrdokrilaca (kornjaši - Coleoptera), porodici krasnika (Buprestidae), podporodici Chrysochroinae Laporte, 1835 te plemenu Dicercini Gistel, 1848. Rasprostranjen je $\mathrm{u}$ širem arealu istočne i zapadne Europe, srednje i jugoistočne Azije te Balkanskog poluotoka, uključujući i Apeninski poluotok (Gobbi i Platia 1995; Kubán 2006). Rod Perotis obuhvaća 15 vrsta. Štetnik je izraziti polifag a napada voćne vrste kao što su badem (Amygdalus comumunis), šljiva (Prunus domestica), marelica ( $P$. armeniaca), trešnja ( $P$. avium), višnja ( $P$. cerasus), trnina (P. spinosa) i pistacija (Pistacia lentiscus) te šumske i ukrasne vrste iz rodova Arbutus spp. (planika), Crataegus spp. (glog), Quercus spp. (hrast) i dr. (Izzillo i Sparacio, 2011). Od voćnih vrsta na području srednje Europe najčešće biljke domaćini su trnina (Prunus spinosa) i marelica (P. armeniaca) (Bílý 2002). Periodični je štetnik koji može napraviti značajne štete, posebno u mladim nasadima voćnih vrsta. Odrasli stadij (imago) pravi štete na nadzemnim organima (kora jednogodišnjih grančica, pupovi i lisne peteljke), dok ličinke prave štete na podzemnim organima (korijen i korijenov vrat). Simptomi napada i štete jednaki su kao kod napada žilogriza (Coleoptera, Buprestidae: Capnodis tenebrionis L.).

Ženke polažu jaja višekratno (ukupno oko 400 - 600) na prizemni dio debla u pukotinama u tlu ili na korijen. Ličinka se hrani u korijenu izgrizajući floem. Kod jačeg napada ličinke mogu u potpunosti uništiti biljku domaćina. Nakon dovršetka razvoja (oko jedne godine) ličinka se kukulji u dijelu korijenovog vrata ili na prizemnom dijelu stabla (Konvička i sur., 2005). Kukuljenje započinje tijekom srpnja i kolovoza, a imaga izlijeću sljedeće godine u travnju i svibnju s vrhuncem pojave u lipnju. Imaga žive od 10 do 50 dana (Bílý 2002; Reichart 1953). Nemaju izražen spolni dimorfizam. Ženke su dužine 15 - $25 \mathrm{~mm}$, a mužjaci do $20 \mathrm{~mm}$. Glava i pokrilje izrazito su sjajne bakrenasto-sive boje. Pokrilje je prošarano uzdužnim prugama s blago uzdignutim svjetlijim i tamnijim pjegama. Jaja štetnika bijele su boje, dužine $1-1,5 \mathrm{~mm}$ i teško su vidljiva na kori ili tlu. Ličinka je crvolika i ima izražene čeljusti crne boje te jako proširen prvi prsni članak. Ličinka živi i hrani se na korijenu i korijenovom vratu koštićavih vrsta, a može narasti u dužinu do 5 cm (Konvička i sur. 2017). Zaštita koštićavog voća od ovog potencijalno značajnog štetnika zahtjevna je i kompleksna, a mjere bi trebale biti usmjerene k preventivi. Mjere suzbijanja trebale bi uključivati mehaničke, agrotehničke, kemijske, a u novije vrijeme i biološke mjere zaštite. Na žalost, ne pronalazimo recentne literaturne podatke o načinima borbe protiv bakrenastoga krasnika pa se sve preporučene mjere zaštite temelje na iskustvima zaštite od žilogriza. Stabla koja pokazuju simptome napada bakrenastoga krasnika potrebno je zajedno s korijenom ukloniti iz nasada, a ličinke uništiti (Kovačević i sur. 1960). Kao preventivne 
mjere preporučuje se da se za podizanje nasada koristi certificirani sadni materijal, dok na iskrčenim površinama ne treba saditi koštićave voćne vrste najmanje 3 do 5 godina. Održavanje nasada u dobroj kondiciji vrlo je važna mjera u prevenciji i zaštiti koštićavih voćnih vrsta (Jovanović 2018). Mehaničke mjere odnose se na skupljanje odraslih jedinki u vrijeme njihove ishrane u krošnjama koštićavih voćaka. U mlađim nasadima skupljanje imaga može se obaviti trešnjom stabala jer se prilikom pada na tlo ne kreću, što omogućava lakše skupljanje (Rotim 2013). Oko stabala mogu se postaviti i PVC folije koje se prekriju tlom ili se na njih postavlja tanka žičana, odnosno plastična mreža s okcima promjera do $2 \mathrm{~mm}$. Svrha postavljenih folija, odnosno mreža jest onemogućavanje ženkama da odlože jaja u neposrednu blizinu stabla (Rotim 2013). Kao agrotehnička mjera koja utječe na smanjenje štetnika preporučuje se češća plića međuredna obrada tla kao i obrada tla u redu u vrijeme kada ženke odlažu jaja. Kako vlažni uvjeti ne odgovaraju razvoju jaja i ličinki, u nasadima u kojima se provodi navodnjavanje zabilježen je znatno manji napad ovoga štetnika (Jovanović, 2018).

Kemijske mjere zaštite odnose se (kao i kod žilogriza) na suzbijanje odraslih oblika kako bi se ženkama onemogućilo polaganje jaja (Tanasijević i Ilić 1969). Novija istraživanja pokazala su da je Sclerodermus abdominalis Westwood iz porodice parazitskih osica (Hymenoptera, Bethylidae) prirodni neprijatelj bakrenastoga krasnika. Ličinke ovih osica parazitiraju ličinke i kukuljice više vrsta kukaca iz porodica Cerambycidae, Scolytidae, Anobiidae, Buprestidae i Bostrichidae (Bohamdan i sur. 2019). Entomopatogene nematode učinkovite su u suzbijanju žilogriza (Marannino i sur. 2003), ali i bakrenastoga krasnika uzrokujući mortalitet kod 95,2\% ličinki (Mohamedova i Lečeva 2015). Entomopatogene gljive učinkovito su biološko sredstvo za suzbijanje značajnijih štetnika u poljoprivrednoj proizvodnji i šumarstvu (Kovač i sur. 2020; Marannino i sur. 2006; Mascarin i Jaronski 2016; Wraight i sur. 2010).

Optimalna temperatura za rast i klijanje entomopatogenih gljiva je između 20 i $30^{\circ} \mathrm{C}$, a učinkovitost entomopatogenih gljiva ovisi i o vrsti gljive i štetnika (Baverstock i sur., 2009). Učinkovitost entomopatogenih gljiva iz rodova Beauveria i Metarhizium ispitana je na žilogrizu (Capnodis spp.) (Marannino i sur. 2006), no koliko nam je poznato, nema objavljenih studija na bakrenastom krasniku.

Cilj je ovog rada prikazati morfološke značajke bakrenastoga krasnika, opisati nastale štete te ispitati po prvi puta učinkovitost entomopatogene gljive u suzbijanju ovog štetnika.

\section{Materijali i metode-Materials and Methods}

Krajem travnja i početkom svibnja 2021. godine na trima lokalitetima u istočnoj Hrvatskoj (katastarske općine (k.o.) Strizivojna, Dalj i Jagodnjak) vizualno su pregledani nasadi šljive, lijeske i višnje kako bi se utvrdila pojava i brojnost populacije odraslih stadija bakrenastoga krasnika. Kukci su mehanički prikupljeni u perforirane plastične posude te čuvani u njima do identifikacije. Ličinke bakrenastoga krasnika prikupljene su sa stabala sa simptomima oštećenja od ličinki. Opisane su i štete na nadzemnim dijelovima mladih nasada. Na lokalitetu u k.o. Strizivojna imago je prikupljen u mladom nasadu šljive (sorta Čačanska rodna) starosti dvije godine, s površine od 0,30 ha $\left(45^{\circ} 14^{\prime} 20,14^{\prime \prime} \mathrm{N} ; 18^{\circ} 24^{\prime} 52,81^{\prime \prime}\right.$ E). U k.o. Jagodnjak prikupljena su imaga i dvije ličinke u nasadu višnje (Oblačinska) starosti 12 godina s površine od 19 hektara

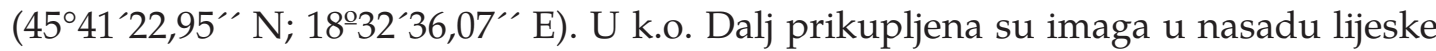
(Tonda di giffoni) starosti od jedne godine s površine od 0,66 hektara $\left(45^{\circ} 30^{\prime} 47,96^{\prime \prime}\right.$ 
N; 18959'40,59” E). Nasadi se obrađuju po principima konvencionalne (šljiva i višnja) te ekološke poljoprivredne proizvodnje (lijeska). Na svim trima lokalitetima na udaljenosti 100 - 300 metara nalaze se šumske površine ili veće površine pod šikarom.

Identifikacija imaga obavljena je u laboratoriju Centra za zaštitu bilja - Hrvatska agencija za poljoprivredu i hranu u Zagrebu. Identifikacija je provedena analizom morfoloških značajki kukca pri čemu je korišten ključ za identifikaciju autora Izzillo i Sparacio (2011).

Osjetljivost bakrenastoga krasnika (P. lugubris) kao i mogućnost biološkog suzbijanja s entomopatogenom gljivom Beauveria bassiana ispitana je na imagu štetnika u centralnom laboratoriju za fitomedicinu Fakulteta agrobiotehničkih znanosti Osijek. Štetnik je prikupljen u nasadu lijeske (Dalj) tijekom svibnja 2021. godine. Provedena su dva pokusa. U prvom pokusu po 10 jedinki imaga bakrenastoga krasnika postavljeno je $\mathrm{u}$ Petri posude na navlažen filter papir u trima ponavljanjima. Štetnici su tretirani komercijalno dostupnim sredstvom Naturalis ${ }^{\circledR}$ (BIOGARD Division, CBC (Europe) S.r.l., Grassobbio, Italy) koji sadrži entomopatogenu gljivu B. bassiana. Na 10 je imaga pomoću automatske pipete primijenjeno $1,5 \mathrm{~mL}$ vodene suspenzije sredstva s koncentracijom $1 \times 10^{8}$ konidija / $\mathrm{mL}$, a u kontrolnom tretmanu kukci su tretirani jednakom količinom vode. Mortalitet kukaca praćen je tijekom 10 dana. Proveden je dodatni pokus $\mathrm{s}$ izvorom hrane za štetnika. Šest bakrenastih krasnika postavljeno je na dvije grane lijeske u entomološki kavez (BugDorm, dimenzija 24,5 x 24,5 x $63 \mathrm{~cm}$ ). Isto biološko sredstvo primijenjeno je $\mathrm{u}$ jednakoj koncentraciji $\left(1 \times 10^{8}\right.$ konidija/mL) kao i u prvom pokusu, ali su provedena dva tretiranja. Krasnici su prskani u entomološkom kavezu prvi puta odmah po postavljanju pokusa i tri dana poslije prvog tretmana. Patogenost entomopatogene gljive praćena je 10 dana. Uginuli kukci izdvojeni su u Petri posude s vlažnim filter papirom te je svakodnevno praćena pojava micelija na kutikuli kukaca. Utvrđen je mortalitet kukaca i pojava micelija.

\section{Rezultati - Results}

U nasadima je prikupljeno ukupno 92 imaga štetnika (slika 1.) i dvije ličinke. Na osnovi morfoloških značajki genitalija mužjaka (aedeagus - slika 2.), ticala (antennae - slika 3.) i prosternalnog detalja ženke (prosternal process) potvrđeno je da su kukci kornjaši iz porodice krasnika (Buprestidae) te da svi pripadaju vrsti Perotis lugubris. Pronađene ličinke pripadaju porodici Buprestidae, no nisu identificirane s pouzdanošću. 


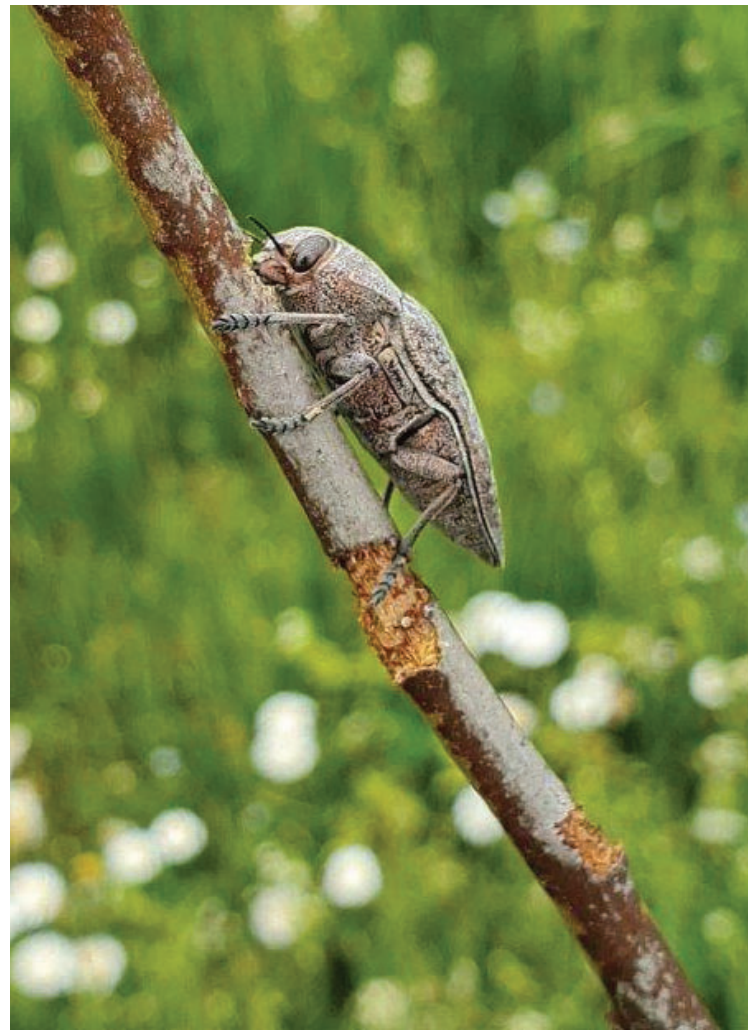

Slika 1. Imago bakrenastoga krasnika izjeda pupove na grani šljive (snimio: T.Validžić, 2021)

Figure 1. The metallic wood-boring beetle adult while feeding on plum tree buds (photo: T. Validžić, 2021)

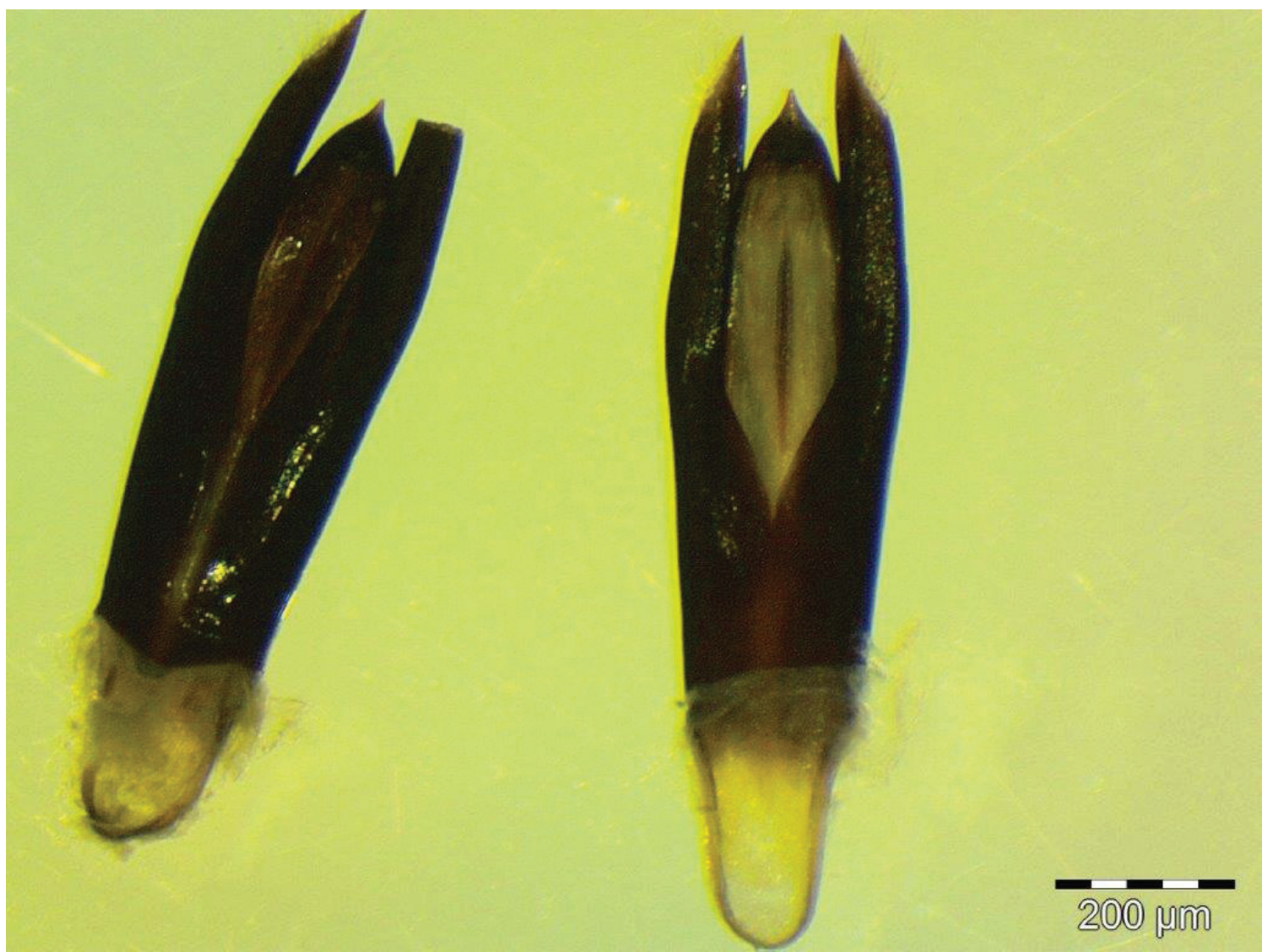

Slika 2. Genitalije mužjaka - aedeagus (snimio: M. Šimala, 2021)

Figure 2. Males genitalia - aedeagus (photo: M. Šimala, 2021) 


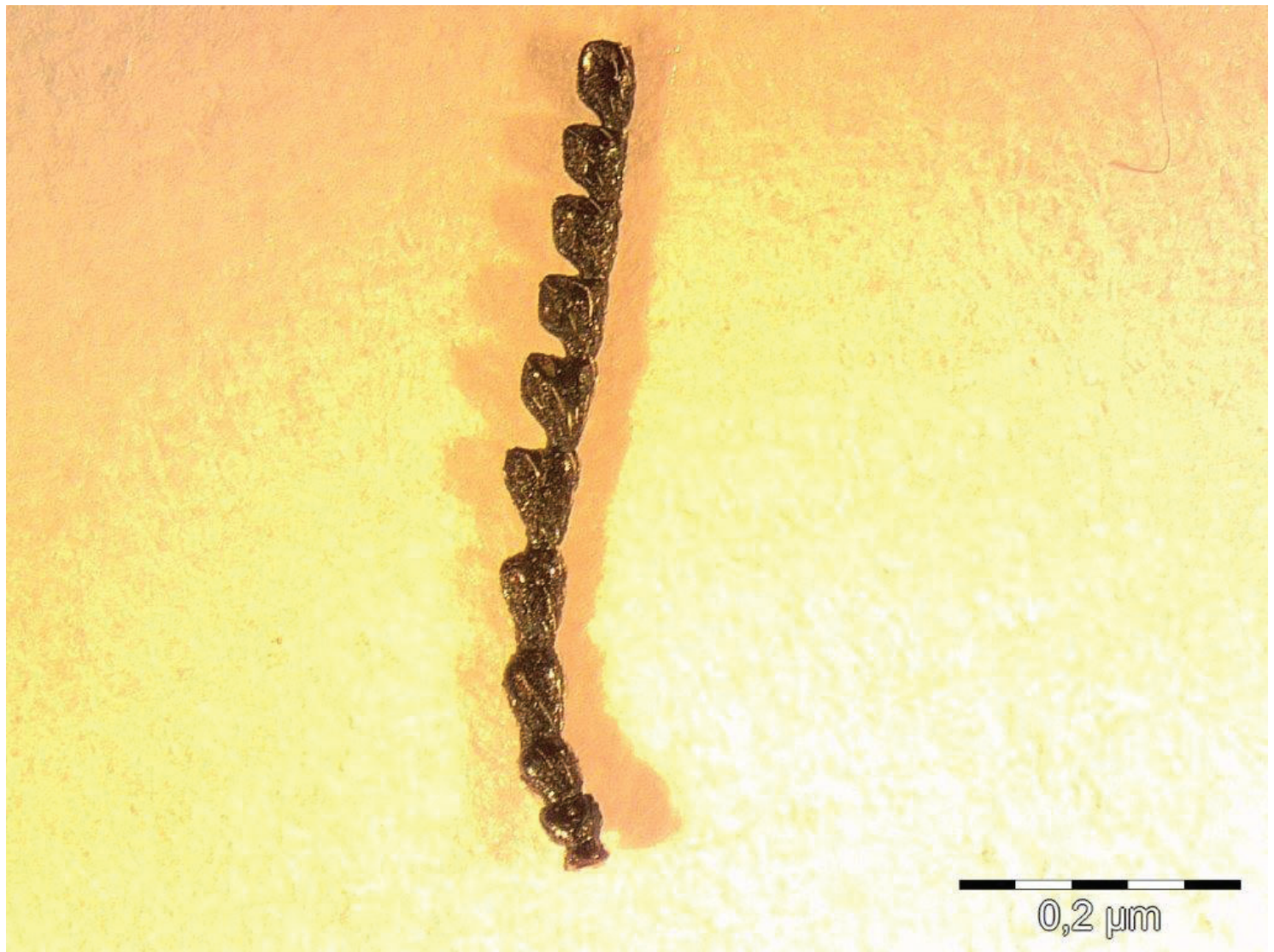

Slika 3. Ticalo ženke - antennae (snimio: M. Šimala, 2021.)

Figure 3. Female antennae (photo: M. Šimala, 2021)

Prosječno na svim lokalitetima utvrđeno je 30\% oštećenih stabala. Na dvogodišnjim sadnicama šljive i jednogodišnjim sadnicama lijeske imago je hraneći se izgrizao pupove i koru uz pupove prošlogodišnjih izbojaka. Na pojedinim sadnicama zabilježeno je i prstenasto izgrizanje kore u visini pupova kao i oštećenje peteljki mladih listova, ali nisu zabilježena oštećenja listova. Utvrđeno je prosječno dva do najviše četiri imaga bakrenastoga krasnika po sadnici. U našem istraživanju četiri imaga bakrenastoga krasnika po sadnici u potpunosti su uništili lateralne pupove što je dovelo do sušenja sadnice. Neke napadnute sadnice potjerale su kasnije iz adventivnih pupova ispod mjesta cijepljenja (podloga), a više sadnica potjeralo je iznad mjesta cijepljenja. Preostali dio sadnice od mjesta rasta adventivnih pupova prema vrhu sadnice osušio se i kasnije je uklonjen rezidbom. Vizualnim pregledom korijena napadnutih mladih sadnica, nisu pronađena oštećenja od ličinki. U starijem nasadu višnje ispod kore korijenovog vrata pronađene su dvije ličinke koje nalikuju ličinkama krasnika, ali ih nije bilo moguće s pouzdanošću identificirati.

U tablici 1. prikazana je učinkovitost entomopatogene gljive $B$. bassiana protiv bakrenastoga krasnika te prva pojava micelija na uginulim kukcima. U prvom pokusu utvrđeno je $60 \%$ uginulih kukaca 10 dana nakon tretmana, dok je u drugom pokusu utvrđen $100 \%$ mortalitet $\mathrm{u}$ jednakom razdoblju. U drugom pokusu obavljena su dva tretmana prskanja, pa je očekivani viši mortalitet kukaca u odnosu na prvi pokus. 
Tablica 1. Patogenost gljive Beauveria bassiana i vrijeme prve pojave micelija na uginulim jedinkama Perotis lugubris

Table 1. Pathogenicity of fungus Beauveria bassiana and the first appearance of mycelium on the Perotis lugubris cadavers

\begin{tabular}{|c|c|c|c|}
\hline $\begin{array}{l}\text { Tretman } \\
\text { Treatment }\end{array}$ & $\mathrm{n}$ & $\begin{array}{l}\text { Ukupni mortalitet (\%) } \\
\text { Total mortality }(\%)\end{array}$ & $\begin{array}{c}\text { Dani nakon tretmana s } \\
\text { prvom pojavom micelija } \\
\text { Days after tretment of first } \\
\text { appearance of mycelium }\end{array}$ \\
\hline $\begin{array}{l}\text { Kontrola } \\
\text { Control }\end{array}$ & 10 & 0 & - \\
\hline Beauveria bassiana (1x108) & 30 & 60 & 5 \\
\hline $\begin{array}{c}\text { Beauveria bassiana (1x108) } \\
\text { (dva tretiranja) + izvor } \\
\text { hrane za kukce } \\
\text { Beauveria bassiana (1x108) } \\
\text { (two treatments) + source } \\
\text { of food for insects }\end{array}$ & 6 & 100 & 7 \\
\hline
\end{tabular}

Pojava micelija na uginulim kukcima (Slika 4.) utvrđena je ranije u pokusu u Petri posudama i to peti dan nakon tretmana kada je micelij primijećen između prsnih članaka s dorzalne strane tijela.

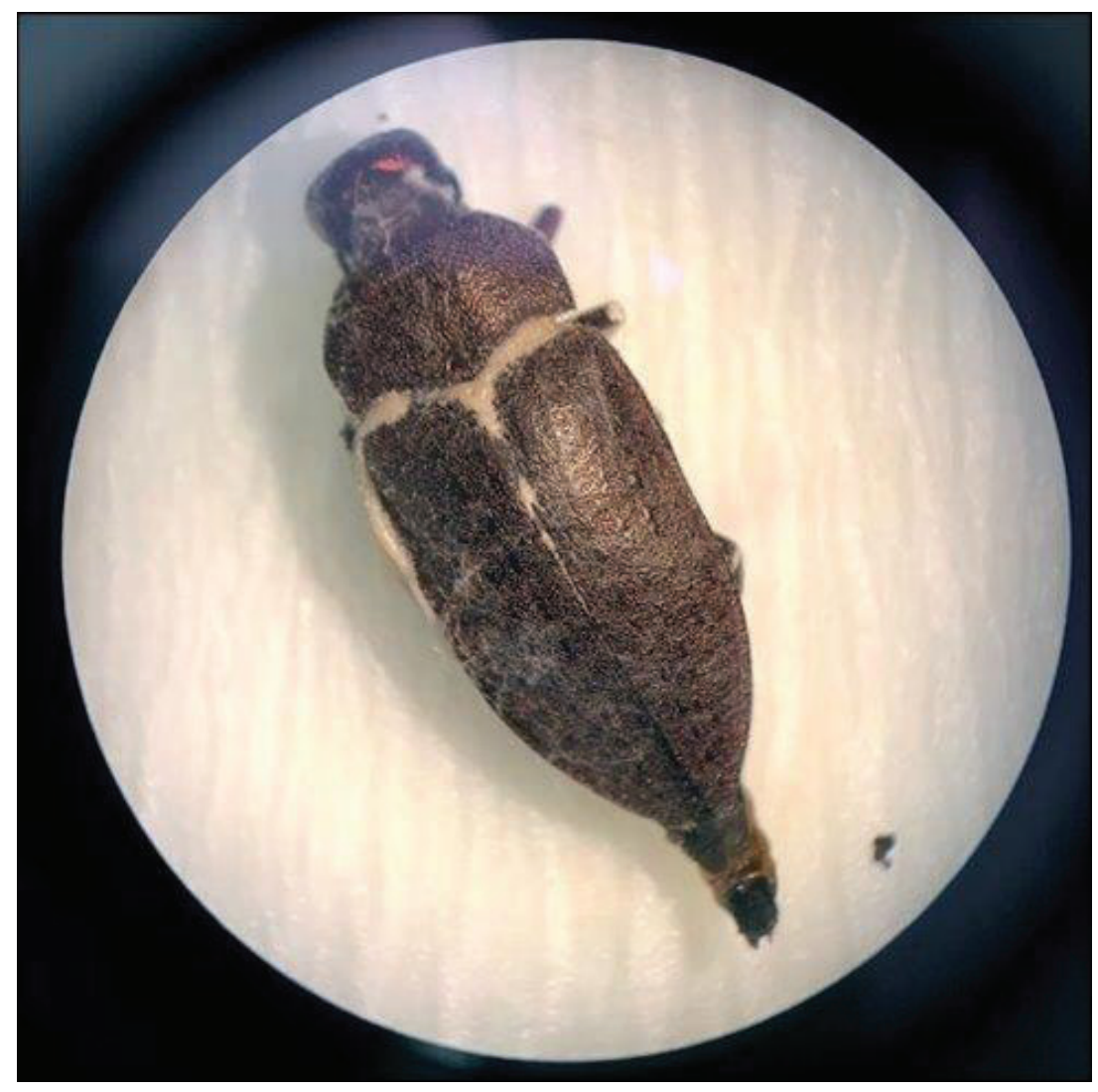

Slika 4. Simptomi zaraze bakrenastoga krasnika (Perotis lugubris) gljive Beauveria bassiana (micelij) (snimila: I. Majić, 2021)

Figure 4. Symptoms of infection of the metallic wood-boring beetle (Perotis lugubris) caused by the fungus Beauveria bassiana (mycelium) (photo: I. Majić, 2021) 


\section{Rasprava - Discussion}

Vrsta P. lugubris ima opisanih pet podvrsta: spp. lugubris, spp. mutabilis, spp. longicollis, spp. transcaspica i spp. meridionalis (Izzillo i Sparacio 2011). Uspoređujući morfološke značajke kukaca prikupljenih u ovom istraživanju s rezultatima studije Izzillo i Sparacio (2011.), genitalije mužjaka slične su podvrsti P. lugubris lugubris prikupljenih u Grčkoj, a ticala su građena kao kod podvrste P. lugubris lugubris prikupljenih u Italiji (Izzillo i Sparacio, 2011). Potrebna su daljnja morfometrijska istraživanja u RH kako bi se usporedile značajke naših populacija ili utvrdile nove podvrste.

U srednjoj Europi (Mađarska, Slovačka i Češka-južna Moravska) tijekom prve polovine 20. stoljeća bakrenasti krasnik bio je prilično uobičajen zajedno sa žilogrizom. No, populacija im je gotovo potpuno nestala s većine lokaliteta. Štetnik je periodično pravio vrlo velike štete u nasadima koštićavog voća. Hoffer (1936) i Kaděra (2011) navode kako je 1935. godine u Češkoj zabilježena masovna pojava bakrenastoga krasnika u mladim nasadima marelice, kada su vlasnici nasada skupljali imaga u posudama te su ih koristili za ishranu svinja i peradi. Međutim, Fleicher (1930) navodi kako je populacija bakrenastoga krasnika $u$ Moravskoj naglo smanjena tijekom prve polovine 20. stoljeća, a gotovo je nestala iz većeg dijela srednje Europe do kraja 20. stoljeća. Vrsta je službeno proglašena u Češkoj kao regionalno izumrla (Škorpík 2005), što je također potvrđeno i u Poljskoj (Burakowski i sur. 1987). Razlog zbog kojeg su navedene vrste gotovo nestale može biti što za svoj razvoj trebaju osunčane prizemne dijelove debla, koji nisu osjenjeni visokom travom. Povoljne uvjete za razvoj osiguravala je ekstenzivna ispaša stoke u voćnim nasadima. Nakon Drugog svjetskog rata ova vrsta napasivanja stoke bila je napuštena te su pašnjaci ovog tipa zamijenjeni otvorenim pašnjacima i livadama s visokom travom te su bakrenasti krasnik i žilogriz izgubili optimalne uvjete za svoj razvoj (Bílý, 2002). Konvička i sur. (2005) navode kako je do naglog izumiranja populacija bakrenastoga krasnika došlo zbog perioda naglog intenziviranja poljoprivredne proizvodnje pedesetih godina 20. stoljeća, smanjenja ekstenzivnih površina za napasivanje stoke, krčenja šuma i terasiranja površina te masovne primjene sredstava za zaštitu bilja.

Od sredine pedesetih godina 20. stoljeća više domaćih autora navodi prisutnost pojedinačnih oštećenja od bakrenastoga krasnika na koštićavom voću, ali bez masovnije pojave štetnika. Tako Kovačević i sur. (1960) navode kako se osim žilogriza, koji dolazi samo u primorskim i južnim krajevima na koštićavim voćkama, u sjevernim krajevima (bivše Jugoslavije - op. Aut.) mogu katkad naći oštećenja korijena koja su slična oštećenjima koje izaziva žilogriz, a potječu od bakrenastoga krasnika. Maceljski (1999) je također utvrdio oštećenja od bakrenastoga krasnika u krošnji voćaka, kao i to da ličinke buše hodnike u korijenju i donjem dijelu debla marelice, šljive, višnje, a rijetko i vinove loze. Tanasijević i Ilić (1969) nazivaju vrstu P. lugubris šiljokrilcem te navode kako se u sjevernim krajevima (bivše Jugoslavije - op. aut.) pojavljuje masovnije nego žilogriz na sličnim voćnim vrstama, kao što je prikazano i u ovom radu. No, isti autori utvrdili su da štetu čine najviše ličinke, ali i da odrasli oblici mogu činiti štete u manjoj mjeri, dok je tijekom našeg praćenja štetnika utvrđeno suprotno. Razlog tomu vjerojatno je činjenica što se radi o prvoj godini masovnije pojave štetnika te o jednogodišnjim i dvogodišnjim sadnicama, s obzirom da se u spomenutoj literaturi navodi da se ličinke češće nalaze u starijem nasadu.

Prema našim spoznajama kritična brojnost ovog štetnika do sada nije utvrđena. Naši rezultati ukazuju da četiri imaga po dvogodišnjoj sadnici šljive i jednogodišnjoj sadnici lijeske uzrokuju 100\% oštećenje na pupovima. Suzbijanje je bakrenastoga krasnika 
zahtjevno jer dio života ovaj štetnik provodi u deblu. Ben-Yehuda i sur. (2000) utvrdili su kako se folijarnom primjenom azinfos-metila postiže najučinkovitije suzbijanje krasnika (žilogriza) u koštićavom voću. U tretmanima debla u kasno proljeće ili prije berbe zadovoljavajuće rezultate imali su pripravci s djelatnom tvari metiokarb, azinfos-metil i karbosulfan. Primjena imidakloprida u tlo $u$ istoj studiji navodi se kao učinkovita zaštita za mlade voćnjake i rasadnike. Za suzbijanje ličinki u korijenu, preporučuju se pripravci na bazi deltametrina na način da se zalijeva zona oko debla. Na žalost, u RH nemamo registriranih kemijskih sredstava za suzbijanje bakrenastoga krasnika. Do sada u literaturi nije navedena osjetljivost ovog štetnika prema entomopatogenim gljivama, no u ovom istraživanju utvrdili smo zadovoljavajući učinak gljive B. bassiana protiv bakrenastoga krasnika. Ovo su prvi takvi objavljeni rezultati i od iznimne su važnosti za poljoprivrednike, osobito one u ekološkom sustavu proizvodnje. Od drugih entomopatogena nematode su također učinkovito biološko sredstvo u borbi protiv ovog štetnika (Mohamedova i Lecheva 2015).

U novije vrijeme, bakrenasti krasnik ponovno je pronađen na pojedinim lokalitetima u srednjoj Europi i Turskoj, ali nisu zabilježene veće štete te je u Češkoj vrsta proglašena kao kritično ugrožena (Roleček i Čižek 2017; Škorpik 2017). Kuzmanović (2013) navodi kako je na obroncima Fruške gore (Srbija) u nasadima šljive i marelice polovinom travnja 2013. godine utvrđeno prisustvo bakrenastoga krasnika čiji napad izaziva sušenje i propadanje stabala te postaje sve značajniji štetnik u Srbiji kao i žilogriz. Jovanović (2018) navodi kako se bakrenasti krasnik pojavljuje u nasadima koštićavog voća u sjevernim dijelovima Srbije (Vojvodina) gdje čini veće štete nego žilogriz, a u proljeće se pojavljuje ranije od žilogriza.

Iz svega navedenog moglo bi se zaključiti kako se početkom 21. stoljeća populacija bakrenastoga krasnika u južnoj i srednjoj Europi ponovno povećava. Razlozi za ovu pojavu nisu do sada istraženi te je nejasno širi li se štetnik od juga prema sjeveru ili od istoka europskog kontinenta prema zapadu. Jedan od razloga mogao bi ležati u činjenici pojave klimatskih ekstrema i globalnog zatopljenja, kao i intenzivne gospodarske aktivnosti (trgovina). Kako u RH do danas nisu prijavljene štete na koštićavim voćkama, a imajući u vidu podatke srbijanskih autora kako štetnik već pravi štete $\mathrm{u}$ Vojvodini, može se očekivati značajan porast populacije bakrenastoga krasnika i u našoj zemlji. Stoga je u sljedećim godinama potrebno provoditi monitoring širenja ovog potencijalno opasnog štetnika u RH.

\section{Zahvala - Acknowledgments}

Zahvaljujemo se mr. sc. Ziti Ladocki Jularić na tehničkoj pomoći pri prikupljanju štetnika te dr. sc. Marti Kovač što je ustupila na korištenje biološko sredstvo za suzbijanje kukaca koje je korišteno u istraživanju.

\section{Literatura - References}

Baverstock, J., Roy, H.E., Pell, J.K. 2009. Entomopathogenic fungi and insect behaviour: from unsuspecting hosts to targeted vectors. U: Roy, H.E., Vega, F.E., Chandler, D., Goettel, M.S., Pell, J., Wajnberg, E. (ur) The Ecology of Fungal Entomopathogens. Springer, Dordrecht. 89-102.

Bílý, S. 2002. Summary of the bionomy of the Buprestid beetles of Central Europe (Coleoptera: Buprestidae). Acta Entomologica Musei Nationalis Pragae, Supplementum. 10: 1-103.

Bohamdan, R., Kassis, W., Bufaur, M. 2019. First record of the biological enemy Sclerodermus abdominalis on Perotis lugubris in Syria. Arab Journal of Plant Protection. 37 (1): 68-70. 
Ben-Yehuda, S., Assael, F., Mendel, Z. 2000. Improved chemical control of Capnodis tenebrionis and C. carbonaria in stone-fruit plantations in Israel. Phytoparasitica. 28: 27-41.

Burakowski, B., Mroczkowski, M., Stefanska, J. 1987. Katalog fauny Polski, Tom 14: Chrząszcze-Coleoptera, Cucujoidea 3. Państwowe wydawnictwo naukowe, Warszawa, 309 str.

Gobbi, G., Platia, G. 1995. Coleoptera Polyphaga VII (Elateroidea, Buprestoidea). U: Minelli, A., Ruffo, S., La Posta, S. (ur), Checklist delle specie della fauna Italiana, Calderini, Bologna, 52 str.

Fleicher, A. 1927-1930. Přehled brouků fauny Československé republiky. Moravské museum zemské, Brno, 485 str.

Hoffer, A. 1936. K abnormálnímu výskytu Perotis lugubris Fbr. na jižní Moravě. Časopis České Společnosti Entomologické (Acta Societatis Entomologicae Bohemiae). 33: 188.

Izzillo, F., Sparacio, I. 2011. A new subspecies of Perotis lugubris Fabricius, 1777 from Southern Italy (Coleoptera, Buprestidae). Biodiversity Journal. 2 (3): 153-159.

Jovanović, S. 2018. Razvojni ciklus i suzbijanje žilogriza i šiljokrilca velikih štetočina voća. Mjesečnik za našu zemlju. 63: 32-33.

Kaděra, M. 2011. Zánik populací některých nápadných brouků jižní Moravy. Časopis ŽIVA. (4): 174-175.

Konvička, O., Hauck, D., Trnka, F., Sekerka, L., Vávra, J., Straka, M., Čížek, L. 2017. Metodika zajištění ochrany a lokalit výskytu vybraných druhů brouků. Biologické centrum AV ČR. Certifikovaná metodika MŽP, 61 str.

Konvička, M., Beneš, J., Čížek, L. 2005. Ohrožený hmyz nelesních stanovišt. Ochrana a management. Sagittaria, Olomouc, 127 str.

Kovač, M., Lacković, N., Pernek, M. 2020. Effect of Beauveria bassiana fungal infection on survival and feeding behavior of pine-tree lappet moth (Dendrolimus pini L.). Forests. 11: 974. https:/ /doi.org/10.3390/f11090974

Kovačević, Ž., Kišpatić, J., Panjan, M. 1960. Bolesti i štetnici voćaka i vinove loze, Poljoprivredni nakladni zavod, Zagreb, 335 str.

Kubán, V. 2006. Buprestidae: Chrysochroinae Dicercini, 346-350. U: Löbl, I., Smetana, A. (ur): Catalogue of Palaearctic Coleoptera, 3. Apollo Books, Stenstrup, 690 p.

Kuzmanović, S. 2013. Šiljokrilac (Perotis lugubris Fab.). Portal Prognozno-izveštajne službe zaštite bilja - Region Ruma. http:/ / www.pisvojvodina.com/RegionRU/Lists/Posts/Post.aspx?ID=18. Preuzeto 24.09.2021.

Maceljski, M. 1999. Poljoprivredna entomologija, Zrinski d.d., Čakovec, 452 str.

Marannino, P., Tarasco, E., de Lillo, E. 2003. Biological notes on larval hatching in Capnodis tenebrionis L. (Coleoptera; Buprestidae) and evaluation of entomopathogenic nematodes in controlling neonate larvae. Redia. 86: 101-105.

Marannino, P., Santiago-Álvarez, C., de Lillo, E., Quesada-Moraga, E. 2006. A new bioassay method reveals pathogenicity of Metarhizium anisopliae and Beauveria bassiana against early stages of Capnodis tenebrionis (Coleoptera; Buprestidae). Journal of Invertebrate Pathology. 93(3): 210-213.

Mascarin, G.M, Jaronski, S.T. 2016. The production and uses of Beauveria bassiana as a microbial insecticide. World Journal of Microbiology and Biotechnology. 32 (11): 1-26.

Mohamedova, M., Lecheva, I. 2015. Efficacy of entomopathogenic nematodes against different stages of the metallic wood-boring beetle, Perotis lugubris Fabricius (Coleoptera: Buprestidae) in laboratory trials. Agrarni Nauki. 7 (17): $105-111$.

Reichart, G. 1953. Contribution a l' etude de la biologie du bupreste bronze (Perotis lugubris). Acta agronomica academiae scientiarum Hungaricae. 3: 71-88.

Roleček, J., Čížek, L. 2017. Recent occurrence of Perotis lugubris (Coleoptera: Buprestidae) in the Czech Republic. Klapalekiana. 53: 337-339.

Rotim, N. 2013. Žilogriz (Capnodis tenebrionis L.) - sve značajniji štetnik koštičavih voćaka, Glasnik zaštite bilja, Zagreb. 6: 55-57.

Škorpik, M. 2005. Buprestidae (krascovití). Pp. 464-468. U: Farkač, J., Kral, D., Škorpik, M. (eds) Červený seznam ohrožených druhů České republiky. Bezobratlí. Invertebrates. Agentura ochrany přrirody a krajiny ČR, Praha, 760 p.

Škorpik, M. 2017. Buprestidae (krascovití). U: Hejda, R., Farkač, J., Chobit, K. (ur): Červený seznam ohrožených druhů České republiky. Bezobratlí. Invertebrates. Př́roda, Praha. 36: 289-294.

Tanasijević, N., Ilić, B. 1969. Posebna entomologija, Izdavačko preduzeće Građevinska knjiga, Beograd, 330 p.

Wraight, S.P., Ramos, M.E., Avery, P.B., Jaronski, S.T., Vandenberg, J.D. 2010. Comparative virulence of Beauveria bassiana isolates against lepidopteran pests of vegetable crops. Journal of invertebrate pathology. 103 (3): 186-199. 